Article

\title{
Impact of Capital Regulation and Market Discipline on Capital Ratio Selection: A Cross Country Study
}

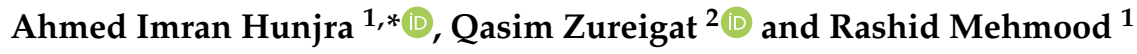 \\ 1 University Institute of Management Sciences, PMAS-Arid Agriculture University Rawalpindi, Punjab 46000, \\ Pakistan; rashidm1005@gmail.com \\ 2 Sulaiman AlRajhi School of Business, Sulaiman AlRajhi University, Al Bukariyah 51941, Al Qassim Province, \\ Saudi Arabia; q.zureigat@sr.edu.sa \\ * Correspondence: ahmedhunjra@gmail.com
}

Received: 23 January 2020; Accepted: 31 March 2020; Published: 3 April 2020

\begin{abstract}
We aim to analyze the impact of capital regulation and market discipline on capital to risk-weighted assets ratio. We used the panel data of Asian developing-countries banks for the period from 2009 to 2018. We collected data from the financial statements of 73 banks of Pakistan, Jordan, Indonesia, the Philippines, Saudi Arabia, and Thailand. We used the generalized method of moment (GMM) to analyze the results. We find that capital regulation and market disciplines significantly influence the capital ratio in Asian developing countries.
\end{abstract}

Keywords: market discipline; capital regulation; capital ratios and financial institutions

JEL Classification: G21; G32

\section{Introduction}

The global financial crisis (GFC) of 2007-2008 affected the world economy. Bank failure influences market development and financial systems that breach the real economy (Berger and Turk-Ariss 2015). Failure of banks results in financial crises, which adversely affect depositors. To safeguard depositors, regulations concerning bank capital and market discipline are important tools. Capital regulation is the value of capital that banks must keep to fulfill the requirements of regulations (Jumreornvong et al. 2018). In 1988, the Basel I accord presented formal capital requirements as bank regulations. Basel II was settled to mitigate the inadequacies of Basel I and to make changes in risk-based capital regulation more effectively (Ashraf et al. 2016).

Capital regulation and market discipline help to improve the stability of financial systems (Kane 2000). Capital regulation effectively improves the banking sector's capital and also influences risk levels. However, implementing capital regulations increase the risk level of banks (Blum 1999). Banks take more risks in response to capital regulation. The effectiveness of capital regulation is important for the stability of the banking sector (Kim and Santomero 1988). In growing economies, the banking sector becomes more competitive, which raises the need for capital regulation. Regulatory authorities describe the rules and regulations related to the banking sector, which help to improve market discipline and bank capital.

It is important to maintain adequate capital for the solvency of banks. For the smooth functioning of the financial sector, Basel II and Basel III highlight the soundness and solvency of banks and require an increase in quality and level of banks' capital (Afzal 2015). If a bank has inadequate reserves, then it is highly levered, which leads to liquidity and credit risk. Capital adequacy ratio determines the level of adequate capital. Sustaining high capital reduces the economic cost of banking crises (Fullenkamp and Rochon 2017). Increased capital ratio secures banks from future losses. The importance 
of capital is evident when banks make investments from their capital; return on equity is high. On the other hand, return on equity of a bank decreases and it has to pay higher borrowing costs when banks make the investment (Xu et al. 2015). In general, when regulatory authorities impose capital ratio pressures on banks, they respond effectively and become more cost-effective. Businesses enjoy growth opportunities across the world through globalization for positive outcomes (Mehmood et al. 2019). In the boom period of the economy, increasing investment via capital and increasing reserves is quite easy, but performing better in the recession period is considerable. In the recession period, reducing the loan amount creates a positive impact on banks, so the availability of capital is more important. We argue that in recession periods, when increasing new capital is costly, banks discourage taking loans for the fulfillment of short period capital requirements (Jackson et al. 1999).

Regulatory authorities' intervention, such as fixing the need for capital for every bank, decreases unexpected bank losses. Maintaining the minimum level of capital increases the confidence of depositors. Shareholders' equity, along with audits, regulations, and credit ratings, give confidence to depositors about their deposited amount. The policy of "Too Big to Fail" indicates that large banks have incentives to take on more risks. Banks must keep a ratio of high quality capital and liquid assets for critical situations. Since the crisis of 2008, the regulatory authorities have reduced capital requirements that reduce leverage ratio so banks are leading to efficiency and solvency. We focus on capital regulation by the bank due to the change in capital requirements or capital regulations. Capital regulatory authorities take more steps to the increase in capital ratio. Banks provide credit to meet the financial needs of the market and borrowers. Banks contribute towards liquidity; further, banks can ensure their soundness by maintaining a minimum limit of capital buffer (Chen and Hsu 2014). It is compulsory for banks to maintain a minimum capital level, as suggested by regulations. The management of banks holds the required level of capital when there is a high equity cost. However, when there is a high level of risk, management needs to increase capital (Romdhane 2012). Therefore, maintaining sufficient capital buffer has become a key aspect, mainly during the time of a financial crisis, to justify the safety of banks. To ensure the application of these banking policies, regulators of banks have developed a minimum limit of capital that may help banks to avoid insolvency. The literature explains the outcomes of capital regulations and market discipline. Afzal (2015) conducted research on market discipline and capital adequacy of banks operating in Pakistan. Zheng et al. (2017) documented that an increase in capital requirements increased the capital adequacy in Bangladesh. Some research work regarding the influences of capital regulations on risk-taking of firms are Jokipii and Milne (2011), Camara et al. (2013), Klomp and Haan (2014), Ashraf et al. (2016), and Jumreornvong et al. (2018).

The economic and business environments of developing countries are quite different from developed countries (Hunjra et al. 2020b). Growth of the capital market in developing countries is low; therefore, banks of developing countries are not sensitive to the market environment. Based on the importance of capital regulations and capital buffer in developing countries, we investigate the impact of capital regulations and market discipline on capital adequacy ratio in developing countries. For this purpose, we selected the countries which follow Basel III requirements of capital. Asian banks are facing strong competition, which puts a negative influence on their risk-taking. The too-big-to-fail principle also applies to Asian banks, mainly when they face poor regulation and supervision (Ahmad and Albaity 2019). Therefore, we selected six countries, including Pakistan, Jordan, Indonesia, the Philippines, Thailand, and Saudi Arabia. These countries are at a growing stage in relation to their banking system. The banking system in these countries is diverse, with different policies and steps of development. The growing banking system of these countries ensures the implementation of regulations. In addition, the implication of Basel II and Basel III are different in selected countries; therefore, we also incorporate individual analysis of each country in order to generate outcomes of capital regulations of each country for a fruitful discussion.

We aim to investigate the impact of capital regulations and market discipline on the capital adequacy ratio of the firms in developing countries. We apply the generalized method of moments and find that capital regulations and market discipline significantly affect the capital adequacy ratio. Because 
less capital reserve increases the chances of bankruptcy, capital regulation has significant importance in developing countries, and results are applicable across the Asian countries, and particularly targeted countries include Pakistan, Indonesia, Jordan, the Philippines, Saudi Arabia, and Thailand.

The remaining parts of the paper are structured as follows. Brief literature is provided in Section 2, followed by data and methodology presented in Section 3. Section 4 deals with empirical results, while Section 5 concludes the paper with insights for further studies.

\section{Literature Review}

In the recent past, countries' lending policies, non-performing loans (NPLs), and the slow buildup of its legal framework became a burden on banks and generated weak capital buffers. Capital regulation remains part of its routine administration. If banks fail to meet the minimum capital requirement, the regulatory commission has the authority to suspend a bank's license or replace its management. The regulatory commission tightens capital regulations through various rules, such as the administrative rules over commercial banks' capital ratio and the notice of capital ratio information disclosure by commercial banks. Developed economies' banks have reported fast-increasing capital ratios since 2003. The buffer theory regarding the requirement of capital explains that if banks maintain the minimum level of capital requirement, they may increase their capital level and control risk. It is reported that when banks hold higher capital ratios, then banks take more risks. It is demonstrated that by adding more risky assets, the probability of bank default increases (Koehn and Santomero 1980). Similarly, it is suggested that risk-based capital requirements encourage banks to choose riskier assets unless and until risk weights are optimally set (Ashraf et al. 2016). Swiss and British banks improve their capital ratios by retaining their risk levels (Tolga Ediz. and Perraudin 1998). Higher probability of bank failure and higher withdrawal rate occurs due to a continuous fall in share prices (Ho and Saunders 1980). The literature claims that, due to capital regulation, the risk exposure of the deposit reduces. Banks can utilize the adequacy of their capital as a way of creating a cost-based advantage in comparison to their competitors. Furlong and Keeley (1989) argue that most value-maximizing banks prefer to maintain higher capital ratios by raising additional capital instead of selling assets. Ghosh and Das (2003) explain that capital regulation affects the behavior of banks and further signifies that banks should maintain the level of capital that is above the required limit. This helps banks to reduce the level of risk. Nilsson et al. (2014) conducted a study while taking a sample of banks in Sweden and found that capital regulations encourage banks to increase capital adequacy ratios. Capital regulation helps value-maximizing when banks invest in highly specialized and risky portfolios ( $\mathrm{Xu}$ et al. 2015). Hence the following hypothesis is built up:

Hypothesis 1 (H1). Capital Regulation Has Significant and Positive Effects on the Capital Adequacy Ratio.

Along with capital regulations, the market discipline also plays a key role in increasing or decreasing the capital adequacy ratio of a bank (Demirgüç-Kunt and Huizinga 2004). The basic purpose of the market disciple is to increase the safety of depositors and escalate the soundness of the market. While considering the competitive market and apart from capital regulation, the market discipline also motivates the banks in developing countries to manage the level of capital adequacy. In addition, Barrios and Blanco (2003), Alfon et al. (2004), and Gropp and Heider (2008) reveal a positive and significant effect of market discipline on capital adequacy ratio. According to Bliss and Flannery (2002), external sanctions on banks are imposed because of market discipline. Depositor behavior, which includes continuous monitoring of bank risks, is the key component of market discipline (Dia and Giuliodori (2012); Wu and Bowe (2012)). In a competitive market, there are incentives for banks to keep capital above the regulatory level. Market discipline significantly influences the level of capital adequacy of banks (Godlewski (2005); Fonseca and González (2010)). We used credit and illiquidity risks and operating ratios to measure market discipline. The literature on different measures presents varying outputs. The operating ratio defines the efficiency of banks. Large financial 
institutions' monthly operating expenses increase the operating cost. Das and Ghosh (2004) investigated the relationship between capital and risk of Indian public sector banks and indicated that capital and risk are negatively associated. Gupta and Mehta (2011) observed the negative correlation between capital adequacy ratio and non-performing assets Indian banks. Another study indicated a negative association between capitalization and the insolvency risk of Indian banks (Maji and Dey 2012). The previous studies point out both negative and positive relationships between bank capital and risk. A positive relationship between capital and risk is observed more in the case of developed countries, while in developing countries, the inverse or insignificant relation is more pronounced. Although the regulatory authorities of respective countries have implemented the adequacy of capital, according to Basel II, market discipline indirectly influences the banking sector to increase the adequacy of capital. Some banks are unable to apply market discipline efficiently, which negatively influences capital adequacy. Therefore, it is important to investigate the profitability of risk-taking the behavior of banks. Afzal (2015) analyzed a study in Pakistan and concluded that market discipline helps the bank to increase the level of capital adequacy. Xu et al. (2015) investigated a study in China and found that operating costs significantly and positively influence the capital adequacy of banks. Therefore, we build up a hypothesis in the following way:

\section{Hypothesis 2 (H2). Market Discipline Has Significant and Positive Effects on the Capital Adequacy Ratio.}

We include profitability, net loan to total assets ratio, bank size, and liquidity as control variables in our study. Profitability is an important factor because capital added by the retained profit positively influences capital buffer. Stolz and Wedow (2011) found a significant and positive effect of profitability on capital adequacy ratios. Liu (2009) found a significant positive correlation between capital and profitability. Moreover, the researchers mostly use profitability as a factor to determine bank capital, while there is less work regarding its influence on the risk-taking behavior of the banks. In reality, banks take more risk in the case of higher profit margins, and they extend loans without any collateral security. The measurement of net loan to total assets ratio represents the ratio of the organization's assets, which is financed with loans or other financial obligations lasting for a long term period or more than one year. Bateni et al. (2014) evaluated a study while taking a sample of private banks in Iran and found that the loan-to-assets ratio significantly and positively influences the capital adequacy ratio. El-Ansary and Hafez (2015) found a significant and positive effect of loans-to-assets ratio on the capital adequacy of commercial banks in Egypt. We also controlled for the effect of firm size on the capital adequacy ratio. Xu et al. (2015) showed a negative impact of bank size on capital adequacy. Afzal (2015) argued that small banks find it difficult to increase depositors. Therefore, small banks cannot generate more capital. We consider leverage as an additional control variable in our model, as in Buyuksalvarci and Abdioglu (2011) and Aktas et al. (2015), who documented a significant and negative impact of bank leverage on the capital adequacy ratio.

\section{Methodology}

We analyzed the impact of capital regulation and market discipline on the banks' capital ratio in Pakistan, Thailand, the Philippines, Jordan, Indonesia, and Saudi Arabia banks. We used panel data in our study, which we collect from audited financial statements of the 73 banks for the period of ten years from 2009 to 2018. Capital adequacy ratio is the total regulatory capital of banks as a proportion of risk-weighted assets (Ashraf et al. 2016). Following Demirgüç-Kunt et al. (2013) and Jumreornvong et al. (2018), we express the capital adequacy ratio (CAR) as risk-adjusted regulatory capital, which is calculated as Tier I capital plus Tier II capital over risk-weighted assets. We use two proxies of capital regulation: capital to risk-weighted assets and deposits. Capital regulation is the capital measured on the basis of bank risk. We refer to capital ratio as capital to risk-weighted assets (Rime 2001; Altunbas et al. 2007). Market discipline is defined as a market promotion due to transparency in financial statements of banks and it confirms information related to the risk of financial 
institutions. We apply two measures of market discipline: operating ratio and credit and illiquidity risk. Therefore, we apply individual models for each market discipline measure, followed by the overall model. This helps us to understand the individual effect of operating ratios and credit and illiquidity risks. We calculate the operating ratio as all operational expenses of banks over all the assets. We calculate credit and illiquidity risks as the ratio of the sum of loans and long term securities divided by sum of cash, balance with the central bank, and short-term securities. Xu et al. (2015) used the same measures of operating ratio and credit and illiquidity risks. We use profitability and net loan to total assets as a control variable. Net loan to total assets represents the credit risk of banks. Higher loan ratios increase interest payments; therefore, it is important to analyze the influence of the net loan on capital adequacy ratio. Profitability defines the business's ability to earn a profit. We calculate this variable as a return on assets. This measure strengthens the analysis as it describes the firm's return on total investment. We measure net loan to total assets as net loans divided by total assets. Xu et al. (2015) applied the same calculations for profitability and net loan to total assets. We measure bank size as the natural logarithm of total assets, as in Afzal (2015) and Hunjra et al. (2020a). Following Zheng et al. (2017), among others, we use total debts to total assets as a proxy of leverage We apply country dummies in our model to consider country characteristics effects.

In our study, we selected all countries with a strong banking sector. Further, we selected banks that are not only from emerging counties but have a strong banking background, fulfilling the Basel-II and Basel-III requirement. Basel-I was introduced in 1988 to strengthen the regulatory requirements of the banks and provided them entry to an international banking system. Basel-II came into play in 2006 to overcome the weaknesses of Basel-I. Due to the global financial crisis, many banks failed, which questioned the existence of Basel-I and Basel-II. Basel III was introduced in 2010 to make up the shortcomings of Basel-I and Basel II, so the banks under study have a strong regulatory background. We use Table 1 for the description of variables.

Table 1. Description of variables.

\begin{tabular}{|c|c|c|c|}
\hline Variables & Sym. & Proxies & Source \\
\hline Capital adequacy ratio & CAR & $\begin{array}{l}\text { Capital ratio = (Tier } 1 \text { capital + Tier } 2 \text { capital)/risk-weighted assets } \\
\text { Tier } 1 \text { capital is defined as the sum of disclosed free reserves, paid-up } \\
\text { capital, statutory reserves minus equity investments in the subsidiary, } \\
\text { brought forward losses and intangible assets, current. } \\
\text { Tier } 2 \text { capital are the sum of undisclosed reserves, general loss reserves, } \\
\text { hybrid debt capital instruments, and subordinated debts. }\end{array}$ & $\begin{array}{l}\text { Jacques and Nigro (1997); } \\
\text { Demirgüç-Kunt et al. (2013); } \\
\text { Jumreornvong et al. (2018) }\end{array}$ \\
\hline \multirow[t]{2}{*}{ Capital regulation } & CAP & $\begin{array}{l}\text { It is measured as the ratio of capital to risk-weighted assets and also } \\
\text { known as a risk-based capital ratio. }\end{array}$ & \multirow{2}{*}{$\begin{array}{l}\text { Rime (2001); Altunbas et al. (2007); } \\
\text { Xu et al. (2015) }\end{array}$} \\
\hline & DEP & Deposits: log of deposits. & \\
\hline \multirow[b]{2}{*}{ Market discipline } & OR & Operating ratio: operating costs over total assets. & \multirow[b]{2}{*}{ Xu et al. (2015) } \\
\hline & RA & $\begin{array}{l}\text { Credit and illiquidity risk: the ratio of the sum of loans and long term } \\
\text { securities divided by sum of cash, balance with the central bank, and } \\
\text { short-term securities. }\end{array}$ & \\
\hline Profitability & PF & Return on assets: the ratio of net income to total assets. & Xu et al. (2015) \\
\hline Net loans to total assets & NLTA & A net loan to the total asset: the ratio of net loans over total assets. & Xu et al. (2015) \\
\hline Bank Size & BS & Natural logarithm of total assets & Afzal (2015); Hunjra et al. (2020c) \\
\hline Leverage & LEV & Total debts over total assets & Zheng et al. (2017) \\
\hline
\end{tabular}

We use the following model:

$$
\begin{aligned}
& (\mathrm{CAR})_{\mathrm{i}, \mathrm{t}}=\beta_{0}+\beta_{1}(\mathrm{CR})_{\mathrm{i}, \mathrm{t}}+\beta_{2}(\mathrm{MD})_{\mathrm{i}, \mathrm{t}}+\beta_{3}(\mathrm{RA})_{\mathrm{i}, \mathrm{t}}+\beta_{4}(\mathrm{OR})_{\mathrm{i}, \mathrm{t}} \\
+ & \beta_{5}(\mathrm{PF})_{\mathrm{i}, \mathrm{t}}+\beta_{6}(\mathrm{NLTA})_{\mathrm{i}, \mathrm{t}}+\beta_{7}(\mathrm{BS})_{\mathrm{i}, \mathrm{t}}+\beta_{8}(\mathrm{LEV})_{\mathrm{i}, \mathrm{t}}+\mathrm{B}_{9}(\mathrm{YD})_{\mathrm{i}, \mathrm{t}} \mu_{\mathrm{t}}(1)
\end{aligned}
$$

where $\mathrm{CAR}=$ capital adequacy ratio; $\mathrm{CR}=$ capital regulation; $\mathrm{MD}=$ market discipline; $\mathrm{RA}=$ credit and illiquidity risks; $\mathrm{OR}=$ operating cost over total assets (deposit interest rate, risk-free interest rate); $\mathrm{PF}=$ profitability; $\mathrm{NLTA}=$ net loan to total assets, $\mathrm{BS}=$ board size; $\mathrm{LEV}=$ leverage; $\mathrm{YD}=$ year dummy 


\section{Empirical Analysis}

We explain the results of the descriptive statistics in Table 2. The descriptive statistics summarized the data of our study.

Table 2. Descriptive analysis.

\begin{tabular}{cccccccc}
\hline & Mean & Median & Q1 & Q3 & Maximum & Minimum & Std. Dev. \\
\hline CAR & 0.175 & 0.138 & 0.107 & 0.176 & 2.387 & 0.007 & 0.199 \\
CAP & 0.132 & 0.113 & 0.087 & 0.141 & 0.816 & 0.005 & 0.101 \\
DEP & 4.529 & 4.220 & 2.987 & 2.388 & 9.156 & 1.242 & 1.988 \\
OR & 0.015 & 0.014 & 0.009 & 0.019 & 0.149 & 0.000 & 0.010 \\
RA & 5.936 & 4.855 & 3.085 & 7.316 & 69.010 & 0.215 & 4.931 \\
PF & 0.013 & 0.013 & 0.008 & 0.018 & 0.159 & -0.207 & 0.019 \\
NLTA & 0.747 & 0.873 & 0.815 & 0.899 & 0.997 & 0.018 & 0.282 \\
BS & 4.650 & 4.327 & 3.116 & 5.475 & 9.233 & 1.458 & 1.973 \\
LEV & 0.493 & 0.496 & 0.336 & 0.634 & 0.835 & 0.009 & 0.201 \\
\hline
\end{tabular}

Note: The above table explains descriptive statistics of variables of our study, which includes mean = average values of variables, $\mathrm{Q} 1$ = first quartile Q3 = third quartile, Std. Dev. = standard deviation of data set, $\mathrm{CAR}=$ capital adequacy ratio; $\mathrm{CAP}=$ capital to assets ratio; $\mathrm{DEP}=$ deposits; $\mathrm{OR}=$ operating ration; $\mathrm{RA}=$ illiquidity risk; $\mathrm{PF}$ = profitability; $\mathrm{NLTA}=$ net loan to total assets, $\mathrm{BS}=$ bank size, $\mathrm{LEV}=$ leverage .

The average value of capital adequacy ratio indicates that banks in selected countries meet the minimum requirement of $8 \%$ (Ashraf et al. 2016). According to Basel II, the minimum limit of capital adequacy is $8 \%$ (Chen and Hsu 2014). Therefore, sample banks of our study across developing countries meet the minimum limit of capital adequacy. However, the minimum value is low, which means that in some of the countries, banks are unable to fulfill the minimum limit of capital adequacy ratio and face high pressure of capital regulation into their system. Further, the mean value of capital to assets ratio indicates that banks are maintaining better capital to finance their assets. Deposits show that banks are creating a better amount of deposits to meet their short term and long-term requirement. However, due to a difference between the maximum and minimum amount of deposits, the standard deviation of deposits is also high. Lower operating ratio explains that banks are well controlling their operating cost. This signifies that the operations of banks are improving their efficiency. Meanwhile, high credit and illiquidity risk with high standard deviation indicates that banks are more prone to bankruptcy risk. Profitability and net loan to total assets are the control variables of our study. The results also show that banks are showing better profitability with the least deviation in the values. Net loan to total assets has a higher mean value, which indicates banks are more loaned-up and their liquidity is low. Average board size indicates that banks are keen to increase their total assets. However, outcomes justify that half of the banks' total assets are financed using debts.

We applied the test of variance inflation factor (VIF) to check multicollinearity in the model, which is reported in Table 3. The values of VIF indicate that no multicollinearity problem exists in the model. We present Pearson's correlation matrix in Table 4, which explains the degree of correlation between the explanatory (independent) variables.

Table 3. Test of multicollinearity.

\begin{tabular}{ccc}
\hline Variables & VIF & $\mathbf{1 / V I F}$ \\
\hline BS & 2.89 & 0.346 \\
DEP & 2.84 & 0.352 \\
LEV & 2.73 & 0.365 \\
NLTA & 2.18 & 0.431 \\
CAP & 1.85 & 0.541 \\
OR & 1.44 & 0.694 \\
RA & 1.21 & 0.829 \\
PF & 1.19 & 0.842 \\
\hline
\end{tabular}

Note: The above table explains the issue of multicollinearity in our data set. VIF = variance inflation factor.

Table 5 represents the effect of capital regulation and market discipline on capital adequacy ratio with the help of a two-step system dynamic regression. We used year dummies in our model to capture the effects of country characteristics. We used the generalized method of moments (GMM) for testing the hypotheses in our study. This research technique handles the issues relating to endogeneity. For this purpose, we used 
two-step dynamic panel regression estimation, which is appropriate for short-period and long cross-sectional data, developed by Arellano and Bond (1991) and Arellano and Bover (1995). The technique deals with autoregressive properties of dependent variables and handles the matter of endogeneity prevailing in dependent variables along with unabsorbed firm specific characteristics (González 2013).

Table 4. Correlation analysis.

\begin{tabular}{cccccccccc}
\hline & CAR & CAP & DEP & OR & RA & PF & NLTA & BS & LEV \\
\hline CAR & 1.000 & & & & & & & & \\
CAP & 0.549 & 1.000 & & & & & & & \\
DEP & -0.266 & -0.297 & 1.000 & & & & & & \\
OR & 0.145 & 0.212 & 0.244 & 1.000 & & & & & \\
RA & -0.097 & 0.018 & -0.296 & -0.246 & 1.000 & & & & \\
PF & 0.150 & 0.049 & 0.004 & -0.329 & 0.009 & 1.000 & & & \\
NLTA & -0.029 & -0.011 & -0.538 & -0.371 & 0.391 & 0.061 & 1.000 & & \\
BS & -0.239 & -0.263 & 0.198 & 0.253 & -0.302 & 0.009 & -0.455 & 1.000 & \\
LEV & -0.152 & -0.032 & 0.071 & 0.172 & 0.412 & 0.041 & 0.211 & 0.219 & 1.000 \\
\hline
\end{tabular}

Note: Table 4 explains the correlation among explanatory variables. $\mathrm{CAR}=$ capital adequacy ratio; $\mathrm{CAP}=$ capital to assets ratio; $\mathrm{DEP}=$ deposits; $\mathrm{OR}=$ operating ration; $\mathrm{RA}=$ illiquidity risk; $\mathrm{PF}=$ profitability; $\mathrm{NLTA}=$ net loan to total assets, BS = bank size, LEV = leverage. The table shows that there is no multicollinearity issue because the highest value of correlation is within range, i.e., less than 0.70 .

We applied the Sargan test to verify the validity of instruments used in our study. Results of the Sargan test show insignificant $p$-values, indicating that instruments are valid. We used the Arellano-Bond test to check autocorrelation. However, findings reveal significant $p$-values of AR1, while insignificant $p$-values AR2, which means we accept the null hypothesis that there is no autocorrelation. Capital to assets ratio is used as a measure of capital regulation. We find that capital to assets ratio has a significant and positive effect on capital adequacy ratio. The result follows the buffer theory proposed by Calem and Rob (1996), which signifies that banks meeting the minimum capital ratio requirement will lead to increasing capital along with a decrease in risk. This also helps them to avoid any regulatory costs that may arise due to not maintaining the minimum capital requirement. This shows that banks in developing countries of the world are following regulations regarding maintaining the minimum capital ratio. In addition, this shows that banks prevent themselves from losses and bankruptcy. Findings also follow the results of $\mathrm{Xu}$ et al. (2015), who observed that there is a significant impact of capital regulations on capital adequacy because this leads banks to prevent losses and bankruptcy. We also used deposits as a tool for measuring capital regulations. We found a significant and negative effect of deposits on the capital adequacy ratio. This is because deposits are a cheaper source of financing as compared to an external source (Weber and Kleff 2003). Therefore, when there is a decrease in the amount of deposits, there is an increase in the cost of external financing, which means banks need more funds to pay the cost of external capital. This shows an inverse relationship between bank deposits and capital adequacy (Bokhari et al. 2012). Positive findings of operating costs are due to the reason that when there is an increase in operating cost, banks demand more capital to efficiently control increasing cost. These findings are similar to the output of $\mathrm{Xu}$ et al. (2015). In addition, mixed findings of credit and illiquidity, especially in the overall model, show that an increase in credit risk reduces the demand for more capital in developing countries.

Among control variables, profitability shows a significant and positive influence on the capital of the banks. The results of profitability on capital adequacy ratio are consistent with the findings of Maji and De (2015), who observe that the positive value of profitability improves the capital of banks. It indicates the bank can improve its capital through retained earnings. The net loan to assets ratio is used to analyze whether the banks are operating well and have the capacity of considerable share in the credit market or not. We find that net loan to total assets ratio has a positive and significant effect on capital adequacy in the first model, while it has a significant but negative effect on capital adequacy in the second and third models which shows a general trend that net loan to total assets ratio reduces capital adequacy ratio of banks. Bank size shows a negative and significant impact on the capital adequacy ratio, which is consistent with the findings of Xu et al. (2015). Leverage has a negative and significant impact on the capital adequacy ratio, as in Aktas et al. (2015), among others. 
Table 5. Two-step system dynamic panel regression (overall).

\begin{tabular}{|c|c|c|c|c|c|c|}
\hline & \multicolumn{2}{|c|}{ Model 1} & \multicolumn{2}{|c|}{ Model 2} & \multicolumn{2}{|c|}{ Model 3} \\
\hline & Coef. & t-Values & Coef. & t-Values & Coef. & $\mathrm{t}$-Values \\
\hline L1. & $0.362^{* * *}$ & $(64.532)$ & $0.561^{* * *}$ & $(41.623)$ & $0.231^{* * *}$ & $(29.020)$ \\
\hline L2. & $-0.015^{* * *}$ & $(-3.623)$ & $-0.112^{* * *}$ & $(-51.236)$ & $-0.115^{* * *}$ & $(-51.136)$ \\
\hline CAP & $1.381^{* * *}$ & $(71.193)$ & - & - & $0.230^{* * *}$ & $(65.935)$ \\
\hline DEP & - & - & $-0.362 * * *$ & $(-36.400)$ & $-0.021^{* * *}$ & $(-24.362)$ \\
\hline OR & $1.655^{* * *}$ & $(12.965)$ & - & - & $0.646^{* * *}$ & $(6.220)$ \\
\hline RA & - & - & 0.002 & $(-0.923)$ & $-0.001^{* * *}$ & $(-10.200)$ \\
\hline $\mathrm{PF}$ & $0.561^{* * *}$ & (62.015) & $0.389^{* * *}$ & $(21.761)$ & $0.561^{* * *}$ & $(23.861)$ \\
\hline NLTA & $0.045^{* * *}$ & $(7.550)$ & $-1.189^{* * *}$ & $(-37.996)$ & $-0.016^{* * *}$ & $(-19.920)$ \\
\hline BS & $-0.161^{* * *}$ & $(5.362)$ & $-0.170 * *$ & $(-2.012)$ & $-0.207^{* * *}$ & $(-4.602)$ \\
\hline LEV & $-0.014^{*}$ & $(-1.695)$ & $-0.002 * *$ & $(-2.022)$ & -0.301 * & $(-1.714)$ \\
\hline Year Dummy & \multicolumn{2}{|c|}{ Yes } & \multicolumn{2}{|c|}{ Yes } & \multicolumn{2}{|c|}{ Yes } \\
\hline $\mathrm{C}$ & $-0.216^{* * *}$ & $(-10.865)$ & $0.695^{* * *}$ & (71.894) & $0.986^{* * *}$ & (39.986) \\
\hline No. of Obs. & \multicolumn{2}{|c|}{782} & \multicolumn{2}{|c|}{782} & \multicolumn{2}{|c|}{782} \\
\hline Sargan & \multicolumn{2}{|c|}{9.361} & \multicolumn{2}{|c|}{6.932} & \multicolumn{2}{|c|}{6.781} \\
\hline$p$-value & \multicolumn{2}{|c|}{0.107} & \multicolumn{2}{|c|}{0.242} & \multicolumn{2}{|c|}{0.225} \\
\hline $\mathrm{AR}_{1}$ & \multicolumn{2}{|c|}{-1.007} & \multicolumn{2}{|c|}{-1.613} & \multicolumn{2}{|c|}{-1.122} \\
\hline$p$-value & \multicolumn{2}{|c|}{0.045} & \multicolumn{2}{|c|}{0.048} & \multicolumn{2}{|c|}{0.043} \\
\hline $\mathrm{AR}_{2}$ & \multicolumn{2}{|c|}{0.613} & \multicolumn{2}{|c|}{0.775} & \multicolumn{2}{|c|}{1.032} \\
\hline$p$-value & \multicolumn{2}{|c|}{0.540} & \multicolumn{2}{|c|}{0.438} & \multicolumn{2}{|c|}{0.302} \\
\hline
\end{tabular}

Note: Table 5 explains the generalized method of moment (GMM) regression results where the capital adequacy ratio is a dependent variable. L1. = first lagged of the dependent variable; L2. = second lagged of the dependent variable; $\mathrm{CAP}=$ capital to assets ratio; $\mathrm{DEP}=$ deposits; $\mathrm{OR}=$ operating ration; $\mathrm{RA}=$ illiquidity risk; $\mathrm{PF}=$ profitability; NLTA = net loan to total assets; $B S=$ bank size; LEV = leverage; Model 1 represents CAP and OR as proxies of capital regulation and market discipline; Model 2 represents DEP and RA as proxies of capital regulation and market discipline; Model 3 represents the overall model with CAP, DEP, OR, and RA as proxies of capital regulation and market discipline. Year Dummy represents the effect of country characteristics, No. of Obs. represents the number of observations, ${ }^{*}, * *, * * *$ represent the level of significance of our analysis at $10 \%, 5 \%$, and $1 \%$, respectively; Sargan $=$ test for over-identifying restrictions, $\mathrm{AR}_{1}=$ Arellano-Bond first-order autocorrelation, $\mathrm{AR}_{2}=$ Arellano-Bond second-order autocorrelation .

Individual country analysis in Table 6 provides some important insights to check the robustness of results. The capital to assets ratio significantly and positively affects capital adequacy across all selected countries of the study, which shows that banks of developing countries are following capital management regulations. Deposits insignificantly influence the capital adequacy ratio for all countries other than Thailand and Indonesia, which shows that the capital adequacy of banks of individual countries other than Thailand and Indonesia depends on external financing sources instead of deposits. The operating ratio has a significant and positive influence on the capital adequacy ratio for Indonesia, the Philippines, and Thailand only. For other countries, we find that the operating ratio has an insignificant effect on the capital adequacy ratio. Credit and illiquidity risks have a significant effect on the capital adequacy of the banks for all sample countries of our study. Profitability shows significant and positive effects on capital adequacy ratio for Indonesia and the Philippines, while it has a significant but negative effect on capital adequacy for Thailand. This explains that banks in Indonesia and the Philippines are well managing their capital adequacy levels with their retained earnings. However, Thailand is still not utilizing its retained earnings to maintain capital adequacy. In addition, we find that other countries are not concerned about managing the levels of capital when they earn more profit. In general, the net loan to total assets ratio shows a significant and negative effect in most of the cases across all the countries other than Jordan, where it shows a negative influence on capital adequacy ratio only in Model 2. Furthermore, we find that board size and leverage significantly and negatively affect the capital adequacy ratio of banks in all countries. In a country-wise analysis, insignificant $p$-values of the Sargan test show that the instruments of our study are valid. Furthermore, significant $p$-values of AR1, while insignificant $p$-values of AR2 in our estimated models, lead us to accept the null hypothesis that there is no issue of autocorrelation. 
Table 6. Two-step system dynamic panel regression (country-wise analysis).

\begin{tabular}{|c|c|c|c|c|c|c|c|c|c|}
\hline \multirow{2}{*}{ Variables } & \multicolumn{3}{|c|}{ Pakistan } & \multicolumn{3}{|c|}{ Jordan } & \multicolumn{3}{|c|}{ Indonesia } \\
\hline & Model 1 & Model 2 & Model 3 & Model 1 & Model 2 & Model 3 & Model 1 & Model 2 & Model 3 \\
\hline L1. & $\begin{array}{c}-0.010 * * * \\
(-6.560)\end{array}$ & $\begin{array}{l}0.252 * * \\
(2.430)\end{array}$ & $\begin{array}{c}-0.115 \\
(-1.371)\end{array}$ & $\begin{array}{l}0.484^{* *} \\
(2.250)\end{array}$ & $\begin{array}{l}0.133^{* *} \\
(2.120)\end{array}$ & $\begin{array}{c}0.004 \\
(0.010)\end{array}$ & $\begin{array}{l}0.107^{* * *} \\
(13.050)\end{array}$ & $\begin{array}{l}0.037^{* * *} \\
(21.570)\end{array}$ & $\begin{array}{l}0.041^{* * *} \\
(14.510)\end{array}$ \\
\hline L2. & $\begin{array}{c}-0.001 \\
(-0.200)\end{array}$ & $\begin{array}{c}0.309^{* * *} \\
(5.771)\end{array}$ & $\begin{array}{c}-0.001 \\
(-0.460)\end{array}$ & $\begin{array}{l}0.129^{*} \\
(1.890)\end{array}$ & $\begin{array}{c}0.145 \\
(1.220)\end{array}$ & $\begin{array}{c}0.049 \\
(0.800)\end{array}$ & $\begin{array}{l}-0.111^{* * *} \\
(-14.830)\end{array}$ & $\begin{array}{l}-0.155^{* * *} \\
(-14.990)\end{array}$ & $\begin{array}{l}-0.132 * * * \\
(-12.450)\end{array}$ \\
\hline CAP & $\begin{array}{l}1.059^{* * *} \\
(71.965)\end{array}$ & - & $\begin{array}{l}1.060^{* * *} \\
(52.362)\end{array}$ & $\begin{array}{l}1.121^{* *} \\
(2.290)\end{array}$ & - & $\begin{array}{c}1.489^{* * *} \\
(3.730)\end{array}$ & $\begin{array}{l}1.416^{* * *} \\
(50.350)\end{array}$ & - & $\begin{array}{c}1.252^{* * *} \\
(8.160)\end{array}$ \\
\hline DEP & - & $\begin{array}{c}-0.022 \\
(-3.742)\end{array}$ & $\begin{array}{c}-0.001 \\
(-0.723)\end{array}$ & - & $\begin{array}{c}0.143 \\
(0.140)\end{array}$ & $\begin{array}{c}0.030 \\
(0.150)\end{array}$ & - & $\begin{array}{c}-0.550^{* * *} \\
(-7.410)\end{array}$ & $\begin{array}{c}-0.464^{* * * *} \\
(7.860)\end{array}$ \\
\hline OR & $\begin{array}{c}-0.001 \\
(-0.100)\end{array}$ & - & $\begin{array}{c}0.019 \\
(0.274)\end{array}$ & $\begin{array}{c}-0.338 \\
(-1.040)\end{array}$ & - & $\begin{array}{c}-0.953 \\
(-0.250)\end{array}$ & $\begin{array}{c}2.087^{* * * *} \\
(8.410)\end{array}$ & - & $\begin{array}{c}1.701^{* * *} \\
(2.290)\end{array}$ \\
\hline RA & - & $\begin{array}{c}0.033^{* * *} \\
(5.431)\end{array}$ & $\begin{array}{c}-0.001 \text { *** } \\
(-3.191)\end{array}$ & - & $\begin{array}{l}-0.004^{* * *} \\
(-12.030)\end{array}$ & $\begin{array}{c}-0.005^{* * *} \\
(-8.730)\end{array}$ & - & $\begin{array}{l}-0.001 \text { ** } \\
(-2.210)\end{array}$ & $\begin{array}{c}-0.003^{* *} \\
(-2.260)\end{array}$ \\
\hline PF & $\begin{array}{c}-0.011 \\
(-0.530)\end{array}$ & $\begin{array}{c}-1.504^{* * *} \\
(-4.642)\end{array}$ & $\begin{array}{c}0.470 \\
(1.012)\end{array}$ & $\begin{array}{l}-1.885 \\
(-1.520)\end{array}$ & $\begin{array}{c}-0.012 \\
(-1.430)\end{array}$ & $\begin{array}{c}0.456 \\
(0.240)\end{array}$ & $\begin{array}{l}1.995^{* * *} \\
(13.250)\end{array}$ & $\begin{array}{c}2.212^{* * *} \\
(9.030)\end{array}$ & $\begin{array}{l}1.972 \text { *** } \\
(24.910)\end{array}$ \\
\hline NLTA & $\begin{array}{c}-0.010^{* * *} \\
(-5.910)\end{array}$ & $\begin{array}{c}-0.274 * * * \\
(-2.771) \\
\end{array}$ & $\begin{array}{l}0.011^{* *} \\
(2.350)\end{array}$ & $\begin{array}{c}-0.949 \\
(-1.130) \\
\end{array}$ & $\begin{array}{c}-0.571^{* * *} \\
(-2.950)\end{array}$ & $\begin{array}{c}-0.158 \\
(-0.130) \\
\end{array}$ & $\begin{array}{l}-1.344 * * * \\
(-26.610)\end{array}$ & $\begin{array}{c}-1.441^{* * *} \\
-37.850) \\
\end{array}$ & $\begin{array}{c}-1.995 * * * \\
(-9.380) \\
\end{array}$ \\
\hline BS & $\begin{array}{l}-0.001 * \\
(-1.680)\end{array}$ & $\begin{array}{l}-0.032 \text { ** } \\
(-2.014)\end{array}$ & $\begin{array}{l}-0.006^{* *} \\
(-2.090)\end{array}$ & $\begin{array}{l}-0.194 * \\
(-1.740)\end{array}$ & $\begin{array}{l}-0.045^{*} \\
(-1.690)\end{array}$ & $\begin{array}{c}0.022 \\
(0.751)\end{array}$ & $\begin{array}{c}-0.002 \\
(-0.120)\end{array}$ & $\begin{array}{c}-0.646^{* * *} \\
(6.010)\end{array}$ & $\begin{array}{c}-0.523 * * * \\
(6.900)\end{array}$ \\
\hline LEV & $\begin{array}{l}-0.012 * * \\
(-2.100)\end{array}$ & $\begin{array}{l}-0.127^{*} \\
(-1.693)\end{array}$ & $\begin{array}{l}-0.266^{* *} \\
(-1.989)\end{array}$ & $\begin{array}{l}-0.112 * \\
(-1.679)\end{array}$ & $\begin{array}{c}0.033 \\
(1.411)\end{array}$ & $\begin{array}{l}0.441^{*} \\
(1.722)\end{array}$ & $\begin{array}{c}-0.004 \\
(-1.062)\end{array}$ & $\begin{array}{l}-0.311 * * \\
(-2.011)\end{array}$ & $\begin{array}{c}-0.301 * * * \\
(-3.219)\end{array}$ \\
\hline $\mathrm{C}$ & $\begin{array}{l}0.002 * \\
(1.471)\end{array}$ & $\begin{array}{c}0.074 \\
(1.411)\end{array}$ & $\begin{array}{c}0.045 \\
(1.164)\end{array}$ & $\begin{array}{c}0.142 \\
(0.310)\end{array}$ & $\begin{array}{l}0.177^{* *} \\
(3.761)\end{array}$ & $\begin{array}{l}0.183^{*} \\
(1.701)\end{array}$ & $\begin{array}{l}1.083^{* * *} \\
(29.960)\end{array}$ & $\begin{array}{l}2.691^{* * *} \\
(61.550)\end{array}$ & $\begin{array}{c}0.066^{* * *} \\
(4.250)\end{array}$ \\
\hline No. of Obs. & 780 & 780 & 780 & 780 & 780 & 780 & 780 & 780 & 780 \\
\hline Sargan & 4.500 & 7.646 & 3.443 & 3.919 & 1.459 & 1.032 & 15.078 & 18.416 & 19.577 \\
\hline$p$-value & 1.000 & 0.998 & 0.998 & 1.000 & 1.000 & 1.000 & 0.999 & 0.998 & 0.998 \\
\hline $\mathrm{AR}_{1}$ & -1.368 & -1.221 & -1.638 & -1.896 & -1.526 & -2.021 & -1.826 & -2.163 & -1.810 \\
\hline$p$-value & 0.041 & 0.037 & 0.041 & 0.052 & 0.025 & 0.039 & 0.045 & 0.051 & 0.045 \\
\hline $\mathrm{AR}_{2}$ & 1.215 & 0.688 & -1.182 & -0.220 & 0.858 & 0.197 & 0.671 & 0.297 & 0.484 \\
\hline$p$-value & 0.224 & 0.492 & 0.237 & 0.826 & 0.391 & 0.844 & 0.502 & 0.766 & 0.629 \\
\hline Variables & \multicolumn{3}{|c|}{ Philippines } & \multicolumn{3}{|c|}{ Thailand } & \multicolumn{3}{|c|}{ Saudi Arabia } \\
\hline L1. & $\begin{array}{c}-0.230^{* * *} \\
(-2.640)\end{array}$ & $\begin{array}{c}-0.042 \\
(-0.100)\end{array}$ & $\begin{array}{l}-0.021 * \\
(-1.781)\end{array}$ & $\begin{array}{l}-0.116^{* * *} \\
(-13.740)\end{array}$ & $\begin{array}{l}-0.229^{* * *} \\
(-13.820)\end{array}$ & $\begin{array}{c}-0.127^{* * *} \\
(-11.350\end{array}$ & $\begin{array}{l}-0.160 * \\
(-1.700)\end{array}$ & $\begin{array}{l}-0.384^{* *} \\
(-2.280)\end{array}$ & $\begin{array}{c}-0.362 \\
(-0.891)\end{array}$ \\
\hline L2. & $\begin{array}{l}0.458^{* * *} \\
(2.220) \\
\end{array}$ & $\begin{array}{c}-0.027 \\
(-0.070) \\
\end{array}$ & $\begin{array}{l}0.304^{* *} \\
(2.490) \\
\end{array}$ & $\begin{array}{l}-0.018^{*} \\
(-1.760) \\
\end{array}$ & $\begin{array}{c}0.134^{* * *} \\
(2.880)\end{array}$ & $\begin{array}{l}0.040 * \\
(1.670) \\
\end{array}$ & $\begin{array}{c}0.032 \\
(0.580) \\
\end{array}$ & $\begin{array}{l}-0.628^{* *} \\
(-2.390) \\
\end{array}$ & $\begin{array}{l}0.052^{*} \\
(1.697) \\
\end{array}$ \\
\hline CAP & $\begin{array}{c}1.205^{* * *} \\
(4.020)\end{array}$ & - & $\begin{array}{c}2.069^{* * *} \\
(5.160)\end{array}$ & $\begin{array}{l}0.688^{*} \\
(1.650)\end{array}$ & - & $\begin{array}{c}1.212 * * * \\
(2.860) \\
\end{array}$ & $\begin{array}{c}1.079^{* * *} \\
(4.400)\end{array}$ & - & $\begin{array}{c}1.330 * * * \\
(9.365)\end{array}$ \\
\hline DEP & - & $\begin{array}{c}1.647 \\
(1.410)\end{array}$ & $\begin{array}{l}0.448^{* *} \\
(2.010)\end{array}$ & - & $\begin{array}{c}0.083 * * * \\
(9.680)\end{array}$ & $\begin{array}{c}0.035 * * * \\
(4.900)\end{array}$ & - & $\begin{array}{c}0.715 \\
(1.051) \\
\end{array}$ & $\begin{array}{c}0.010 \\
(1.061)\end{array}$ \\
\hline OR & $\begin{array}{l}1.347^{* *} \\
(2.440)\end{array}$ & - & $\begin{array}{l}1.254^{*} \\
(1.690)\end{array}$ & $\begin{array}{l}1.614^{* * *} \\
(11.770)\end{array}$ & - & $\begin{array}{c}0.757^{* * *} \\
(3.650)\end{array}$ & $\begin{array}{c}-0.897 \\
(-1.160)\end{array}$ & - & $\begin{array}{c}1.985 \\
(0.621)\end{array}$ \\
\hline RA & - & $\begin{array}{c}-0.003 \\
(-0.760)\end{array}$ & $\begin{array}{l}-0.002 * \\
(-1.689)\end{array}$ & - & $\begin{array}{l}-0.001 \text { ** } \\
(-1.710)\end{array}$ & $\begin{array}{c}-0.001^{* * *} \\
(-2.850)\end{array}$ & - & $\begin{array}{c}-0.003 \\
(-1.360)\end{array}$ & $\begin{array}{c}-0.002 * * * \\
(-7.113)\end{array}$ \\
\hline PF & $\begin{array}{l}0.975^{*} \\
(1.981)\end{array}$ & $\begin{array}{c}0.368 \\
(1.360)\end{array}$ & $\begin{array}{l}0.047^{*} \\
(1.770)\end{array}$ & $\begin{array}{c}-0.127^{* * *} \\
(-9.480)\end{array}$ & $\begin{array}{l}-0.606^{* * *} \\
(-15.960)\end{array}$ & $\begin{array}{c}-0.230^{* * *} \\
(-9.450)\end{array}$ & $\begin{array}{c}1.896 \\
(1.230)\end{array}$ & $\begin{array}{c}1.502 \\
(1.362)\end{array}$ & $\begin{array}{l}0.531 * \\
(1.681)\end{array}$ \\
\hline NLTA & $\begin{array}{l}-1.062 * \\
(-1.930)\end{array}$ & $\begin{array}{l}-0.239^{*} \\
(-1.810)\end{array}$ & $\begin{array}{l}0.703^{* *} \\
(2.080)\end{array}$ & $\begin{array}{l}-0.556^{* *} \\
(-1.320)\end{array}$ & $\begin{array}{l}-0.971^{* * *} \\
(-71.660)\end{array}$ & $\begin{array}{c}-0.041 \\
(-0.100)\end{array}$ & $\begin{array}{l}-0.693^{*} \\
(-1.780)\end{array}$ & $\begin{array}{l}-1.803^{* *} \\
(-1.992)\end{array}$ & $\begin{array}{c}1.955 \\
(0.782)\end{array}$ \\
\hline BS & $\begin{array}{l}-0.098^{* *} \\
(-2.230)\end{array}$ & $\begin{array}{l}-0.815^{*} \\
(-1.712) \\
\end{array}$ & $\begin{array}{l}-0.424^{*} \\
(-1.870)\end{array}$ & $\begin{array}{c}-0.026^{* * *} \\
(2.840)\end{array}$ & $\begin{array}{c}-0.063 \\
(-1.570)\end{array}$ & $\begin{array}{l}-0.005^{*} \\
(-1.890)\end{array}$ & $\begin{array}{l}-0.002 * \\
(-1.794)\end{array}$ & $\begin{array}{l}-0.091 \text { ** } \\
(-2.210)\end{array}$ & $\begin{array}{l}-0.331^{*} \\
(1.689)\end{array}$ \\
\hline LEV & $\begin{array}{c}-0.336 \\
(-1.051) \\
\end{array}$ & $\begin{array}{l}-0.991 * \\
(-1.711)\end{array}$ & $\begin{array}{c}0.007^{* * *} \\
(3.001)\end{array}$ & $\begin{array}{l}-0.309^{* *} \\
(-2.066)\end{array}$ & $\begin{array}{c}0.071 \\
(1.096) \\
\end{array}$ & $\begin{array}{c}-0.962 \text { *** } \\
(-4.622)\end{array}$ & $\begin{array}{c}-0.112 \\
(-1.221) \\
\end{array}$ & $\begin{array}{l}-0.115^{* *} \\
(-2.125)\end{array}$ & $\begin{array}{l}-0.334 * \\
(-1.693) \\
\end{array}$ \\
\hline C & $\begin{array}{l}-1.612^{* *} \\
(-2.250)\end{array}$ & $\begin{array}{c}1.166^{* * *} \\
(3.220)\end{array}$ & $\begin{array}{l}-0.805^{* *} \\
(-2.310)\end{array}$ & $\begin{array}{c}0.471 \\
(1.090) \\
\end{array}$ & $\begin{array}{l}1.367^{* * *} \\
(44.910)\end{array}$ & $\begin{array}{l}-0.045 \\
(0.110) \\
\end{array}$ & $\begin{array}{c}-0.624 \\
(-1.490) \\
\end{array}$ & $\begin{array}{c}0.475 \\
(0.320) \\
\end{array}$ & $\begin{array}{l}-0.169 * \\
(-1.762) \\
\end{array}$ \\
\hline No. of Obs. & 780 & 780 & 780 & 780 & 780 & 780 & 780 & 780 & 780 \\
\hline Sargan & 3.148 & 2.337 & 2.106 & 6.075 & 6.281 & 8.027 & 1.894 & 2.984 & 2.663 \\
\hline$p$-value & 1.000 & 1.000 & 0.999 & 1.000 & 0.998 & 1.000 & 0.999 & 1.000 & 1.000 \\
\hline $\mathrm{AR}_{1}$ & -1.866 & -1.446 & -2.055 & -1.415 & -1.164 & -1.396 & -0.278 & -0.842 & -1.114 \\
\hline$p$-value & 0.042 & 0.012 & 0.040 & 0.071 & 0.035 & 0.043 & 0.057 & 0.049 & 0.043 \\
\hline $\mathrm{AR}_{2}$ & 0.017 & 0.352 & -0.617 & 1.199 & 0.260 & 1.689 & 0.551 & -0.987 & -0.862 \\
\hline$p$-value & 0.986 & 0.725 & 0.537 & 0.231 & 0.877 & 0.091 & 0.581 & 0.236 & 0.553 \\
\hline
\end{tabular}

Note: Table 5 explains GMM regression results where the capital adequacy ratio is a dependent variable. L1. $=$ first lagged of the dependent variable; L2. = second lagged of dependent variable; CAP = capital to assets ratio; $\mathrm{DEP}=$ deposits; $\mathrm{OR}=$ operating ration; $\mathrm{RA}=$ illiquidity risk; $\mathrm{PF}=$ profitability; NLTA = net loan to total assets; $\mathrm{BS}=$ bank size; $\mathrm{LEV}=$ leverage; Model 1 represents CAP and OR as proxies of capital regulation and market discipline; Model 2 represents DEP and RA as proxies of capital regulation and market discipline; Model 3 represents the overall model with CAP, DEP, OR, and RA as proxies of capital regulation and market discipline, No. of Obs. represents number of observations, ${ }^{*}, * * * * *$ represent level of significance of our analysis at $10 \%, 5 \%$, and $1 \%$, respectively. Sargan $=$ test for over-identifying restrictions, $\mathrm{AR}_{1}=$ Arellano-Bond first-order autocorrelation, $\mathrm{AR}_{2}=$ Arellano-Bond second-order autocorrelation. 


\section{Conclusions}

Capital adequacy of banks represents an important aspect of the management of banks and regulatory authorities. Therefore, the aim of our study is to examine the impact of capital regulation and market discipline on the capital weighted risk assets ratio of listed banks in Asian developing countries. We applied the GMM approach to analyse the results. We find that, due to compulsory capital regulation, banks have increased the capital buffers and lowered the risk levels. The findings of our study signify that capital regulations have a significant influence on capital adequacy ratios, which ensure that following the regulations of maintaining capital effectively contributes to improve adequacy ratio of capital. The increase in the levels of capital and decrease in risk levels help banks in developing countries to overcome regulatory costs arising due to the inability to maintain minimum capital requirements. In addition, this leads banks to avoid bankruptcy and losses. We document a significant but inverse effect of deposits on the capital adequacy ratio of banks. This signifies that when there is a decline in deposits, this leads to an increase the cost of external financing, implying that banks need more financing to pay the cost of external capital. Therefore, there is an inverse relationship between bank deposits and capital adequacy. We also find that banks in developing countries follow the buffer theory of capital by maintaining the minimum requirement of capital in order to avoid an increased level of risk. Regarding market discipline, we found that market discipline significantly influences the capital ratio. However, credit and illiquidity risks show a significant and negative effect on capital adequacy in the first model, but an insignificant effect on the capital adequacy ratio in the second model.

In the banking sector, market discipline enhances productivity by compelling the financial institution that is not working well to become effective. Our study finds evidence to support the presence of market discipline in the banking system of selected Asian developing countries and confirms its effect on the level of bank capitalization. From the above discussion, we find that capital regulation directly contributes capital moment of banks in developing Asian countries. Developing countries increase their capital buffer, which results in decreasing the risk level through the implementation of capital regulation. The profitability ratio shows a positive effect on capital adequacy, and the bank has preferred to increase its capital through retained earnings instead of issuing new equity. However, the level of net loan to total assets indicates the banking sector has to decrease the capital buffer, especially when the banking sector slows down. Our study focuses on capital requirements that eliminate the chances of bankruptcy. By maintaining a higher level of capital buffers, banks contribute to the stability and solvency of the banking system as a whole and push risky banks to become better capitalized.

The practical implication of this paper for policymakers as a market discipline can complement the state's regulatory role. The findings of our study justify that, while following regulatory requirements of capital, banks are able to increase their capital, which helps to mitigate risk. Although the results show that capital requirements decrease the probability of bankruptcy, which positively influences capital ratio, still further improvements in the regulatory system can enhance efficiency and improve the stability of banks in developing countries. Further, the outcomes of banks may lead to the solvency and solidity of the overall system of banks if they follow the regulatory requirements of their capital. In addition, outcomes of our study explain that imposing market discipline and capital regulations help risk-taking banks to generate better capital. This is due to the fact that when the risk level is high, banks keep a high amount of capital. Therefore, risk-based capital regulation helps to decrease bank risk in developing countries. An increase in the capital adequacy ratio of one bank relative to the industry reduces its cost of borrowing, especially when banks maintain a higher level of capital adequacy ratio to retain their financial resources and reduce the cost of funding in the presence of market discipline. This study covers only selected developing countries of Asia, a comparative analysis of developed and developing countries may be a good study, with pre- and post-financial crises scenarios. 
Author Contributions: A.I.H. worked on conceptualization, writing-original draft preparation, writing一review and editing, supervision, Q.Z. handles the methodology, software and formal Analysis, whereas R.M. contributes in resources, data curation and formal analysis. All authors have read and agreed to the published version of the manuscript.

Funding: This research received no external funding.

Conflicts of Interest: The authors declare no conflict of interest.

\section{References}

Afzal, Ayesha. 2015. The Impact of Market Discipline on Banks' Capital Adequacy: Evidence from an Emerging Economy. The Lahore Journal of Business 4: 61-73.

Ahmad, Rubi, and Mohamed Albaity. 2019. The Determinants of Bank Capital for East Asian Countries. Global Business Review 20: 1311-23. [CrossRef]

Aktas, Rafet, Bilge Bakin, and Gokhan Celik. 2015. The Determinants of Banks' Capital Adequacy Ratio: Some Evidence from South Eastern European Countries. Journal of Economics and Behavioral Studies 7: 79-88. [CrossRef]

Alfon, Isaac, Isabel Argimon, and Patricia Bascuñana-Ambrós. 2004. What Determines How Much Capital Is Held by UK Banks and Building Societies? London: Financial Services Authority.

Altunbas, Yener, Santiago Carbo, Edward P. M. Gardener, and Philip Molyneux. 2007. Examining the relationships between capital, risk and efficiency in European banking. European Financial Management 13: 49-70. [CrossRef]

Arellano, Manuel, and Stephen Bond. 1991. Some tests of specification for panel data: Monte Carlo evidence and an application to employment equations. The Review of Economic Studies 58: 277-97. [CrossRef]

Arellano, Manuel, and Olympia Bover. 1995. Another look at the instrumental variable estimation of error-components models. Journal of Econometrics 68: 29-51. [CrossRef]

Ashraf, Badar Nadeem, Sidra Arshad, and Yuancheng Hu. 2016. Capital regulation and bank risk-taking behavior: Evidence from Pakistan. International Journal of Financial Studies 4: 16. [CrossRef]

Barrios, Víctor E., and Juan M. Blanco. 2003. The effectiveness of bank capital adequacy regulation: A theoretical and empirical approach. Journal of Banking E Finance 27: 1935-58.

Bateni, Leila, Hamidreza Vakilifard, and Farshid Asghari. 2014. The influential factors on capital adequacy ratio in Iranian banks. International Journal of Economics and Finance 6: 108-16. [CrossRef]

Berger, Allen N., and Rima Turk-Ariss. 2015. Do depositors discipline banks and did government actions during the recent crisis reduce this discipline? An international perspective. Journal of Financial Services Research 48: 103-26. [CrossRef]

Bliss, Robert R., and Mark J. Flannery. 2002. Market discipline in the governance of US bank holding companies: Monitoring vs. influencing. Review of Finance 6: 361-96. [CrossRef]

Blum, Jürg. 1999. Do capital adequacy requirements reduce risks in banking? Journal of Banking $\mathcal{E}$ Finance 23: 755-71.

Bokhari, Ijaz Hussain, Syed Muhamad Ali, and Khurram Sultan. 2012. Determinants of Capital Adequacy Ratio in Banking Sector: An Empirical Analysis from Pakistan. Academy of Contemporary Research Journal 11: 1-9.

Buyuksalvarci, Ahmet, and Hasan Abdioglu. 2011. Determinants of capital adequacy ratio in Turkish Banks: A panel data analysis. African Journal of Business Management 5: 11199.

Calem, Paul S., and Rafael Rob. 1996. The Impact of Capital-Based Regulation on Bank Risk-Taking: A Dynamic Model. Washington, DC: Division of Research and Statistics, Division of Monetary Affairs, Federal Reserve Board.

Camara, Boubacar, Laetitia Lepetit, and Amine Tarazi. 2013. Ex-ante capital position, changes in the different components of regulatory capital and bank risk. Applied Economics 45: 4831-56. [CrossRef]

Chen, Yi-Kai, and Ching-Lan Hsu. 2014. Are Bank Capital Buffers Cyclical-Evidence for Developed and Developing Countries. Journal of Financial Studies 22: 27-56.

Das, Abhiman, and Saibal Ghosh. 2004. The relationship between risk and capital: Evidence from Indian public sector banks. RBI Occasional Papers Summer 22: 1-21.

Demirgüç-Kunt, Asli, and Harry Huizinga. 2004. Market discipline and deposit insurance. Journal of Monetary Economics 51: 375-99. [CrossRef]

Demirgüç-Kunt, Asli, Enrica Detragiache, and Ouarda Merrouche. 2013. Bank Capital: Lessons from the Financial Crisis. Journal of Money, Credit and Banking 45: 1147-64. [CrossRef] 
Dia, Enzo, and Massimo Giuliodori. 2012. Portfolio separation and the dynamics of bank interest rates. Scottish Journal of Political Economy 59: 28-46. [CrossRef]

Tolga Ediz., Ian Michael, and William Perraudin. 1998. Bank Capital Dynamics and Regulatory Policy. Working paper. London: Bank of England.

El-Ansary, Osama, and Hassan Hafez. 2015. Determinants of capital adequacy ratio: An empirical study on Egyptian banks. Corporate Ownership \& Control 13: 1-10.

Fonseca, Ana Rosa, and Francisco González. 2010. How bank capital buffers vary across countries: The influence of cost of deposits, market power and bank regulation. Journal of Banking E Finance 34: 892-902.

Fullenkamp, Connel, and Céline Rochon. 2017. Reconsidering bank capital regulation: A new combination of rules, regulators, and market discipline. Journal of Economic Policy Reform 20: 343-59. [CrossRef]

Furlong, Frederick T., and Michael C. Keeley. 1989. Capital regulation and bank risk-taking: A note. Journal of Banking E Finance 13: 883-91.

Ghosh, Saibal, and Abhiman Das. 2003. Market Discipline in the Indian Banking Sector: An Empirical Exploration. Mumbai: NSE Research Initiative, NSE, pp. 1-19.

Godlewski, Christophe J. 2005. Bank capital and credit risk-taking in emerging market economies. Journal of Banking Regulation 6: 128-45. [CrossRef]

González, Víctor M. 2013. Leverage and corporate performance: International evidence. International Review of Economics \& Finance 25: 169-84.

Gropp, Reint, and Florian Heider. 2008. The Determinants of Capital Structure: Some Evidence from Banks. Discussion Paper No. 08-015. Frankfurt: Centre for economic European Research.

Gupta, Vinod Kumar, and Meera Mehta. 2011. Indian banks and Basel-II: An econometric analysis. Indian Journal of Finance 5: 11-19.

Ho, Thomas, and Anthony Saunders. 1980. A catastrophe model of bank failure. The Journal of Finance 35: 1189-207. [CrossRef]

Hunjra, Ahmed Imran, Tahar Tayachi, and Rashid Mehmood. 2020a. How Do Corporate Social Responsibility and Corporate Governance Affect Stock Price Crash Risk? Journal of Risk and Financial Management 13: 30. [CrossRef]

Hunjra, Ahmed Imran, Uzma Perveen, Leon Li, Muhammad Irfan Chani, and Rashid Mehmood. 2020b. Impact of ownership concentration, institutional ownership and earnings management on stock market liquidity. Corporate Ownership \& Control 17: 77-87.

Hunjra, Ahmed Imran, Tahar Tayachi, and Rashid Mehmood. 2020c. Impact of ownership ownership structure on risk-taking behavior of South Asian Banks. Corporate Ownership E Control 17: 108-20.

Jackson, Patricia, Craig Furfine, Hans Groeneveld, Diana Hancock, David Jones, William Perraudin, Lawrence Radecki, and Masao Yoneyama. 1999. Capital Requirements and Bank Behaviour: The Impact of the Basle Accord (No. 1). Basel: Bank for International Settlements.

Jacques, Kevin, and Peter Nigro. 1997. Risk-based capital, portfolio risk, and bank capital: A simultaneous equations approach. Journal of Economics and Business 49: 533-47. [CrossRef]

Jokipii, Terhi, and Alistair Milne. 2011. Bank capital buffer and risk adjustment decisions. Journal of Financial Stability 7: 165-78. [CrossRef]

Jumreornvong, Seksak, Chanakarn Chakreyavanich, Sirimon Treepongkaruna, and Pornsit Jiraporn. 2018. Capital adequacy, deposit insurance, and the effect of their interaction on bank risk. Journal of Risk and Financial Management 11: 79. [CrossRef]

Kane, Edward J. 2000. Designing Financial Safety Nets to Fit Country Circumstances. World Bank Policy Research Working Paper. Washington, DC: The World Bank.

Kim, Daesik, and Anthony M. Santomero. 1988. Risk in banking and capital regulation. The Journal of Finance 43: 1219-33. [CrossRef]

Klomp, Jeroen, and Jakob De Haan. 2014. Bank regulation, the quality of institutions, and banking risk in emerging and developing countries: An empirical analysis. Emerging Markets Finance and Trade 50: 19-40. [CrossRef]

Koehn, Michael, and Anthony M. Santomero. 1980. Regulation of bank capital and portfolio risk. The Journal of Finance 35: 1235-44. [CrossRef]

Liu, Dinglin. 2009. Listed commercial banks' intellectual capital performance positive analysis. Modern Corporation Culture 26: 169-71. 
Maji, Santi Gopal, and Utpal Kumar De. 2015. Regulatory capital and risk of Indian banks: A simultaneous equation approach. Journal of Financial Economic Policy 7: 140-56. [CrossRef]

Maji, Santi Gopal, and Soma Dey. 2012. Credit and insolvency risks of Indian commercial banks: Do size and capitalization matter. JM International Journal of Finance 2: 47-59.

Mehmood, Rashid, Ahmed Imran Hunjra, and Muhammad Irfan Chani. 2019. The Impact of Corporate Diversification and Financial Structure on Firm Performance: Evidence from South Asian Countries. Journal of Risk and Financial Management 12: 49. [CrossRef]

Nilsson, Victor, Joakim Nordstrom, and Krister Bredmar. 2014. Need for liquidity and the capital structure of Swedish banks following the financial crisis. International Journal of Finance and Banking Studies 3: 10-27. [CrossRef]

Rime, Bertrand. 2001. Capital requirements and bank behavior: Empirical evidence for Switzerland. Journal of Banking E Finance 25: 789-805.

Romdhane, Mohamed. 2012. The Determinants of Banks' Capital Ratio in Developing Countries: Empirical Evidence from Tunisia. Research Journal of Finance and Accounting 3: 35-46. [CrossRef]

Stolz, Stéphanie, and Michael Wedow. 2011. Banks' regulatory capital buffer and the business cycle: Evidence for Germany. Journal of Financial Stability 7: 98-110. [CrossRef]

Weber, Martin, and Volker Kleff. 2003. How Do Banks Determine Capital?_Empirical Evidence for Germany. Discussion Paper, 03-66. Mannheim: ZEsW-Leibniz Centre for European Economic Research.

$\mathrm{Wu}$, Yuliang, and Michael Bowe. 2012. Information disclosure and depositor discipline in the Chinese banking sector. International Financial Markets, Institution and Money 22: 855-78. [CrossRef]

Xu, Lei, Shih-Cheng Lee, and Yishu Fu. 2015. Impacts of capital regulation and market discipline on capital ratio selection: Evidence from China. International Journal of Managerial Finance 11: 270-84. [CrossRef]

Zheng, Changjun, Mohammed Mizanur Rahman, Munni Begum, and Badar Nadeem Ashraf. 2017. Capital regulation, the cost of financial intermediation and bank profitability: Evidence from Bangladesh. Journal of Risk and Financial Management 10: 9. [CrossRef]

(C) 2020 by the authors. Licensee MDPI, Basel, Switzerland. This article is an open access article distributed under the terms and conditions of the Creative Commons Attribution (CC BY) license (http://creativecommons.org/licenses/by/4.0/). 